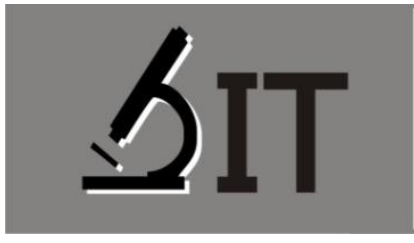

p-ISSN : 2597-8977

e-ISSN : 2597-8985

Ridha Alfiana

SMPN 2 Wotu

Ratnawaty Mamin

Universitas Negeri Makassar

Sitti Rahma Yunus

Universitas Negeri Makassar
*) Correspondence Author: ridha.alfiana@gmail.com
JIT 2 (1) (2018) 88-94

JURNAL IPA TERPADU

http://ojs.unm.ac.id/index.php/ipaterpadu

\section{PENGARUH METODE PEMBELAJARAN PQ4R (PREVIEW, QUESTION, READ, REFLECT, RECITE, $R E V I E W)$ TERHADAP HASIL BELAJAR PESERTA DIDIK KELAS VII SMP NEGERI 3 PALANGGA KABUPATEN GOWA}

Abstrak: Penelitian ini adalah penelitian eksperimen semu yang bertujuan untuk mengetahui pengaruh Metode PQ4R (Preview, Question, Read, Reflect, Recite, Review) terhadap hasil belajar peserta didik kelas VII SMPN 3 Palangga Kabupaten Gowa. Variabel bebas dalam penelitian ini adalah Metode PQ4R dan metode konvensional dan variabel terikatnya adalah hasil belajar peserta didik Kelas VII SMPN 3 Palangga pada materi pokok Ekosistem. Populasi penelitian ini adalah kelas VII SMPN 3 Palangga yang terdiri atas 7 kelas dengan peserta didik sebanyak 208 peserta didik. Teknik pengambilan sampel yaitu double random sampling. Sampel penelitian terdiri dari 2 kelas yaitu kelas VII2 sebagai kelas eksperimen dengan jumlah peserta didik 30 dan kelas VII4 sebagai kelas kontrol dengan jumlah peserta didik 30 orang. Penelitian ini menggunakan Instrument soal pilihan ganda untuk mengukur hasil belajar peserta didik dan lembar observasi keterlaksanaan model. Teknik pengumpulan data yang dilakukan dengan memberikan pretest dan posttest dan dengan menggunakan lembar keterlaksanaan model. Data hasil penelitian pretest dan posttest kemudian dianalisis dengan analisis deskriptif dengan nilai rata-rata kelas eksperimen 33 dan kelas kontrol 30,7 pada pretest, pada posttest rata-rata kelas eksperimen adalah 85,83 dan kelas kontrol 79,63. Setelah analisis deskriptif dilakukan analisis inferensial menggunakan uji-t. Hasil analisis statistik inferensial thitung $=3,4>t(0,05 ; 58)=1,67$, maka dapat disimpulkan bahwa Metode PQ4R (Preview, Question, Read, Reflect, Recite, Review) berpengaruh terhadap hasil belajar peserta didik kelas VII SMPN 3 Palangga pada materi pokok Ekosistem.

Kata Kunci: PQ4R, hasil belajar, ekosistem.

Abstract: This study is a quasi-experimental study that aims to know the effect of PQ4R Method (Preview, Question, Read, Reflect, Recite, Review) to learning result of students in class VII SMPN 3 Palangga Gowa. The independent variable in this research are $\mathrm{PQ} 4 \mathrm{R}$ and conventional method and the dependent variable is learning result of students in Class VII of SMPN 3 Palangga in Subject Matter ecosystem. Population in this research are class VII of SMPN 3 Palangga that consist of 7 classes with 208 students. Techniq are of taking sample is simple random sampling. Sample of this research consist of two classes that is VII 2 as experiment class with 30 students and VII4 as the control class with 30 students. This study uses multiple choice questions to measure learners' learning outcomes and model model observation sheets. Data collection techniques performed by giving pretest and posttest and using keterlaksanaan sheet models. Data of pretest and posttest result were analyzed by descriptive analysis with mean value of experiment class 33 and control class 30,7 at pretest, on experiment class average posttest was 85,83 and control class 79,63. After the descriptive analysis is done inferential analysis using $\mathrm{t}$-test. Result data 
gained with pretest and posttest then analyzed by t-test. Statistic inferential analysis result was get by Tamount $=3.4>t(0.05 ; 58)=1.67$, so that concluded that PQ4R method (Preview, Question, Read, Reflect, Recite, Review) has influenced to Learning Result Students Class VII of SMPN 3 Palangga Gowa (Subject Matter of Ecosystem).

Keyword: PQ4R, learning result, ecosystem

\section{PENDAHULUAN}

Di zaman modern ini, pendidikan merupakan kebutuhan yang sangat penting bagi masyarakat pada umumnya. Hal ini terlihat dari banyaknya masyarakat diusia sekolah yang mengenyam pendidikan di berbagai tingkat sekolah mulai dari sekolah dasar sampai tingkat perguruan tinggi. Tujuan pendidikan juga tercantum dalam UUD 1945 yaitu, Tujuan Pendidikan Nasional adalah mencerdaskan kehidupan bangsa dan mengembangkan manusia Indonesia seutuhnya, yaitu manusia yang beriman dan bertaqwa terhadap Tuhan Yang Maha Esa dan berbudi pekerti luhur, memiliki pengetahuan dan keterampilan, kesehatan jasmani dan rohani, kepribadian yang mantap dan mandiri serta rasa tanggung jawab kemasyarakatan dan kebangsaan.

Dengan adanya pendidikan, maka akan timbul dalam diri seseorang untuk berlomba-lomba dan memotivasi diri untuk lebih baik dalam segala aspek kehidupan. Selain itu pemerintah juga mencanangkan wajib belajar 12 tahun bagi seluruh rakyat Indonesia, hal ini juga yang merupakan kewajiban bagi seluruh rakyat Indonesia usia sekolah untuk mengenyam pendidikan. Pendidikan merupakan salah satu syarat untuk lebih memajukan negara, maka pemerintah mengusahakan pendidikan mulai dari tingkat SD sampai minimal SMA.

Berdasarkan hasil observasi yang dilakukan pada salah satu pendidik di SMP Negeri 3 palangga, Kabupaten Gowa bulan April 2017 menyatakan bahwa hasil belajar IPA pada semester ganjil tahun ajaran 2016/2017 sangat rendah dengan nilai rata-rata adalah 62,04 dimana nilai tersebut belum mencapai standar Kriteria Ketuntasan Minimal (KKM) yaitu 70. Hal tersebut dikarenakan kurangnya minat dan motivasi belajar dari peserta didik itu sendiri dilihat pada saat proses pembelajaran peserta didik yang tidak menyimak penjelasan pendidik atau melakukan kegiatan selain belajar selama proses pembelajaran berlangsung.

Salah satu metode pembelajaran yang dapat diterapkan dalam melibatkan secara aktif guna menunjang kelancaran proses belajar mengajar adalah penerapan metode pembelajaran PQ4R. Metode ini mampu memancing keaktifan peserta didik dalam proses belajar mengajar. Hal ini disebabkan karena peserta didik dituntut untuk menemukan jawaban sendiri dengan keterampilan membaca yang dituntut dalam setiap langkah metode PQ4R sehingga pemahaman peserta didik menjadi meningkat. Adapun langkah metode PQ4R terdiri dari enam langkah pembelajaran yaitu preview, question, read, reflect, recite, dan review.

Berdasarkan hasil penelitian yang dilakukan oleh Agus et al, (2014) bahwa peserta didik yang belajar dengan metode pembelajaran preview, question, read, reflect, recite, dan review (PQ4R) secara signifikan memperoleh hasil belajar IPA yang lebih baik daripada peserta didik yang menggunakan metode PQ4R. Hasil penelitian tersebut sesuai dengan hasil penelitian yang dilakukan oleh Sudiarti et al, (2015) bahwa terdapat perbedaan yang signifikan antara peserta didik yang belajar dengan metode pembelajaran PQ4R dengan peserta didik yang belajar dengan metode konvensional, dimana peserta didik yang diajarkan menggunakan metode $\mathrm{PQ} 4 \mathrm{R}$ lebih tinggi hasil belajarnya dibandingkan dengan peserta didik yang belajar menggunakan metode konvensional.

Metode pembelajaran PQ4R menuntut peserta didik lebih aktif dalam proses belajar. Selain itu pendidik harus mampu untuk mendesain progam pembelajarannya. Hal tersebut dilakukan agar 
menjadikan proses pembelajaran menjadi efektif, efisien dan menarik. Dengan kelebihan metode pembelajaran $\mathrm{PQ} 4 \mathrm{R}$ yaitu dapat membantu peserta didik yang daya ingatannya lemah untuk menghafal konsep-konsep pelajaran, maka penulis merasa tertarik untuk melakukan penelitian lebih mendalam, penelitian ini diberijudul "Pengaruh Metode Pembelajaran PQ4R (Preview, Question, Read, Reflect, Recite, Review) terhadap hasil belajar peserta didik kelas VII SMPN 3 Palangga Kabupaten Gowa (Studi Pada Materi Pokok Ekosistem)".

Berdasarkan uraian latar belakang di atas, maka rumusan masalah pada penelitian ini adalah "Apakah terdapat pengaruh metode pembelajaran PQ4R (Preview, Question, Read, Reflect, Recite, Review) terhadap hasil belajar peserta didik kelas VII SMPN 3 Palangga Kabupaten Gowa (Studi Pada Materi Pokok Ekosistem)?"

Berdasarkan rumusan masalah di atas, maka tujuan penelitian ini adalah untuk mengetahui pengaruh Metode Pembelajaran PQ4R (Preview, Question, Read, Reflect, Recite, Review) terhadap hasil belajar peserta didik kelas VII SMPN 3 Palangga Kabupaten Gowa (Studi Pada Materi Pokok Ekosistem).

\section{METODE}

Jenis penelitian Eksperimental-Semu (quasi-experimental research) dengan desain penelitian Nonequivalent Control Group Design. Populasi penelitian ini adalah peserta didik kelas VIII SMP Negeri 3 Pallangga pada tahun ajaran 2016/2017 yang terdiri dari kelas dengan jumlah peserta didik 208 orang. dan diambil dua kelas yang terdiri dari kelas VII2 sebagai kelas kontrol dengan jumlah peserta didik 26 orang dan kelas VII4 sebagai kelas eksperimen dengan jumlah peserta didik 30 orang.

Instrumen yang digunakan dalam penelitian ini adalah tes hasil belajar yang digunakan untuk mengukur pemahaman peserta didik tentang pokok bahasan ekosistem yang terdiri dari 25 butir soal pilihan ganda. Analisis data dalam penelitian ini meliputi: Analisis deskriptif dan Analisis inferensial. Analisis deskriptif ini digunakan untuk mendeskripsikan nilai hasil belajar IPA yang diajar dengan menggunakan metode $\mathrm{PQ} 4 \mathrm{R}$ yang terdiri dari nilai rata-rata (mean), standar deviasi, nilai tertinggi dan nilai terendah. Sedangkan analisis inferensial digunakan untuk uji normalitas data dengan menggunakan rumus chi-kuadrat, uji homogenitas dengan membandingkan varian terbesar dengan varian terkecil menggunakan uji-f dan pengujian hipotesis dengan menggunakan uji-t.

\section{HASIL DAN PEMBAHASAN}

Berikut ini disajikan rangkuman nilai hasil belajar peserta didik pada kelas eksperimen dan kelas kontrol

Tabel 1. Statistik Nilai Pretest Kelas Eksperimen dan Kelas Kontrol

\begin{tabular}{ccc}
\hline Statistik & Kelompok Eksperimen & Kelompok Kontrol \\
\hline Jumlah Sampel & 30 & 30 \\
Nilai Terendah & 48 & 40 \\
Nilai Tertinggi & 20 & 20 \\
Nilai Rata-rata & 33 & 30,7 \\
Standar Deviasi & 8,74 & 6,81 \\
Varians & 76,6 & 46,5 \\
\hline
\end{tabular}


Tabel 2. Statistik Nilai Posttest Kelas Eksperimen dan Kelas Kontrol

\begin{tabular}{ccc}
\hline Statistik & Kelompok Eksperimen & Kelompok Kontrol \\
\hline Jumlah Sampel & 30 & 30 \\
Nilai Terendah & 48 & 40 \\
Nilai Tertinggi & 20 & 20 \\
Nilai Rata-rata & 33 & 30,7 \\
Standar Deviasi & 8,74 & 6,81 \\
Varians & 76,6 & 46,5 \\
\hline
\end{tabular}

Tabel 3. Persentase Pencapaian Tiap Indikator Kelas Eksperimen dan Kelas Kontrol

\begin{tabular}{|c|c|c|c|c|}
\hline \multirow{2}{*}{ No. } & \multirow{2}{*}{ Indikator } & \multirow{2}{*}{ Nomor Soal } & \multicolumn{2}{|c|}{ PersenTase Pencapaian Indikator (\%) } \\
\hline & & & Kelas eksperimen & Kelas kontrol \\
\hline 1. & Menjelaskan pengertian ekosistem & 1 & 100 & 97 \\
\hline 2. & $\begin{array}{l}\text { Mengidentifikasi komponen } \\
\text { ekosisem }\end{array}$ & $2,3,4$ & 96 & 90 \\
\hline 3 & $\begin{array}{l}\text { Mengidentifikasi satuan-satuan } \\
\text { dalam ekosistem }\end{array}$ & $5,6,7,8$ & 88 & 83 \\
\hline 4. & $\begin{array}{l}\text { Menggambarkan dalam bentuk } \\
\text { diagram rantai makanan dan jaring- } \\
\text { jaring makanan }\end{array}$ & $9,10,11,12,13,14$ & 73 & 66 \\
\hline 5 & $\begin{array}{l}\text { Mengidentifikasi tingkat trofik dalam } \\
\text { piramida makanan }\end{array}$ & $15,16,17$ & 84 & 73 \\
\hline 6. & $\begin{array}{l}\text { Mengidentifikasi interaksi antar } \\
\text { ekosistem }\end{array}$ & $18,19,20,21$ & 93 & 83 \\
\hline 7. & $\begin{array}{l}\text { Menjelaskan jenis-jenis ekosistem } \\
\text { perairan }\end{array}$ & 22 & 90 & 80 \\
\hline 8. & $\begin{array}{l}\text { Mendeskripsikan bioma } \\
\text { padaekosistem daratan }\end{array}$ & $23,24,25$ & 90 & 89 \\
\hline & Rata-rata & & $89,25 \%$ & $82,6 \%$ \\
\hline
\end{tabular}

Data yang diperoleh dari penelitian ini selain dianalisis secara deskriptif juga digunakan analisis inferensial dengan statistik uji-t yang bertujuan untuk pengujian hipotesis. Sebelum digunakan uji-t pada uji hipotesis, terlebih dahulu dilakukan uji prasyarat (uji normalitas dan homogenitas).

Hasil analisis inferensial chi-kuadrat hasil belajar kelas eksperimen pada data nilai pretest didapatkan $\chi 2_{\text {hitung }}=10,84$ dan data nilai postest didapatkan $\chi 2_{\text {hitung }}=3,12$ dengan nilai $\chi 2$ tabel untuk $d k$ =5 pada taraf signifikansi 0,05 adalah 11,07, sehingga data pretest dan postest hasil belajar peserta didik kelas eksperimen berdistribusi normal karena $\chi 2_{\text {hitung }}<\chi 2_{\text {tabel. }}$. Perolehan data yang berasal dari populasi yang juga berdistribusi normal didapatkan pada kelas kotrol pada data nilai pretest $\chi{ }^{2}$ hitung $=7,82$ dan nilai postest $\chi 2$ hitung $=4,39$ dan $\chi 2$ tabel pada taraf signifikansi 0,05 dengan $\mathrm{dk}=5$ diperoleh 11,07 dapat dilihat bahwa nilai $\chi 2$ hitung $<\chi 2$ tabel.

Berdasarkan data kelas ekperimen dan kelas kontrol hasil uji homogenitas yang disajikan pada lampiran $\mathrm{F}$ dengan mengunakan varians dari kelas eksperimen sebagai varians terbesar dan varians pada kelas kontrol sebagai varians terkecil sehingga dari hasil perhitungan tersebut diperoleh nilai $F_{\text {hitung }}=1,037$ dengan $F_{\text {tabel }}=1,8$ maka kedua data memiliki varians yang homogen. Pada uji hipotesis ini digunakan uji-t Diperoleh nilai $t_{\text {hitung }}=3,4$ dan nilai $t_{\text {tabel }}$ pada taraf kepercayaan 0,05 dan $\mathrm{dk}=58$ sebesar 1,67. Dengan membandingkan nilai thitung dan ttabel diperoleh $t_{\text {hitung }}>$ $t_{\text {tabel, }}$ artinya Ho ditolak dan $\mathrm{H} 1$ diterima. Sehingga dapat disimpulkan bahwa hasil belajar peserta 
didik yang dibelajarkan dengan mengunakan metode PQ4R lebih tinggi daripada hasil belajar peserta didik yang dibelajarkan tanpa mnggunakan metode PQ4R pada materi ekosistem.

Penelitian ini dilakukan di SMP Negeri 3 Palangga yang bertujuan untuk mengetahui pengaruh pada hasil belajar IPA peserta didik yang diajarkan menggunakan metode PQ4R dengan yang diajar menggunakan pembelajaran konvensional. Berdasarkan hasi analisis satistik secara deskriptif menujukkan bahwa hasil belajar IPA peserta didik kelas VII SMP Negeri 3 Palangga yang menggunakan metode $\mathrm{PQ} 4 \mathrm{R}$ pada kelas eksperimen lebih tinggi dibandingkan dengan peserta didik yang diberi pembelajaran konvensional pada kelas kontrol. Hal ini dapat dilihat pada pembelajaran menggunakan metode $\mathrm{PQ}_{4} \mathrm{R}$ pada posttest kelas eksperimen lebih tinggi dibandingkan nilai hasil belajar IPA pada pembelajaran konvensional pada posttest kelas kontrol. Dimana pada kelas eksperimen hanya 1 peserta didik yang tidak tuntas dari 30 peserta didik kelas eksperimen, sedangkan pada kelas kontrol terdapat 5 orang peserta didik tidak tuntas dari 30 orang pesera didik pada posttest kelas kontrol, dengan menggunakan satandar KKM 70.

Pencapaian tiap indikator menunjukkan hasil belajar IPA kelas eksperimen lebih tinggi dibandingkan dengan kelas kontrol. Selanjutnya pada kelas ekperimen rata-rata persentase pencapaian indikator sebesar $89,25 \%$ sedangkan rata-rata pencapaian indikator kelas kotrol sebesar $82,6 \%$. Adapun rata-rata pretest hasil belajar peserta didik pada kelas kontrol dan kelas eksperimen berturut-turut dengan nilai 30,7 dan 33, hal tersebut menandakan bahwa perolehan nilai pada pretest atau nilai hasil belajar peserta didik di awal pembelajaran tergolong rendah disebabkan materi yang disampaikan belum dibelajarkan kepada peserta didik sehingga mereka hanya menjawab pertanyaan sesuai dengan pengalaman yang mereka dapatkan dalam kehidupan seharihari. Nilai rata-rata posttest hasil belajar kelas kontrol sebesar 79,63 dan nilai rata-rata posttest hasil belajar kelas eksperimen 85,83 . Hal tersebut dikarenakan pada kelas ekperimen peserta didik dituntut untuk membaca keseluruhan materi dan membuat pertanyaan, kemudian menjawab pertanyaan dengan membaca kembali materi, sehingga peserta didik dapat lebih aktif dalam pembelajaran, hal ini sejalan dengan (Trianto, 2007) metode belajar PQ4R melatih peserta didik untuk mandiri dalam proses dalam pembelajaran, karena metode PQ4R dapat digunakan untuk meningkatkan kemampuan peserta didik dalam belajar dan peserta didik dapat mengingat materi yang disajikan dalam bentuk bahan bacaan.

Berdasarkan hasil analisis di atas yang menggunakan uji pihak kanan dan membuktikan $\mathrm{H} 1$ diterima dan Ho ditolak yang berarti bahwa terdapat perbedaan hasil belajar IPA peserta didik kelas VII SMP Negeri 3 Palangga yang diajar menggunakan metode PQ4R. Hal ini dibuktikan dengan hasil analisis data menunjukkan bahwa $t_{\text {hitung }}=3,4>t_{\text {tabel }}=1,67$. Sehingga dapat dinyatakan bahwa terdapat pengaruh metode PQ4R terhadap hasil belajar IPA peserta didik kelas VII SMP Negeri 3 Palangga studi pada materi ekosistem, hal ini sesuai dengan penelitian yang telah dilakukan oleh Andi Afrisal, (2013) diperoleh bahwa metode PQ4R berpengaruh positif yang ditandai dengan peningkatan hasil belajar yang signifikan. Hal ini sejalan dengan hasil penelitian yang dilakukan oleh Agus, et al (2014) peserta didik yang belajar dengan metode pembelajaran preview, question, read, reflect, recite, review (PQ4R) secara signifikan memperoleh hasil belajar IPA yang lebih baik daripada siswa yang menggunakan metode pembelajaran konvensional.

Hasil belajar IPA peserta didik setelah diterapkan metode PQ4R lebih tinggi dibandingkan dengan metode pembelajaran konvensional disebabkan oleh beberapa faktor. Salah satu diantaranya yaitu peserta didik lebih aktif selama proses pembelajaran karena peserta didik terlibat langsung selama proses pembelajaran sehingga peserta didik mudah memahami inti dari materi yang disampaikan hal ini sejalan dengan (Wahyuningsih, 2012) pembelajaran dengan metode PQ4R dapat meningkatkan keaktifan peserta didik karena peserta didik sendiri yang menemukan ide pokok, menggali pertanyaan dan jawaban, mengaitkan ide pokok satu dengan yang lainnya sehingga sampai pada kesimpulan dari bacaan yang diberikan.

Hasil analisis data menunjukkan bahwa hasil belajar IPA peserta didik di kelas eksperimen lebih tinggi daripada di kelas kontrol. Artinya, ketuntasan dan keberhasilan pembelajaran di kelas 
eksperimen lebih tinggi daripada di kelas kontrol. Sehingga dapat dikatakan bahwa terdapat pengaruh metode PQ4R terhadap hasil belajar IPA peserta didik kelas VII SMP Negeri 3 Palangga studi pada materi pokok ekosistem

\section{KESIMPULAN}

Berdasarkan hasil penelitian dan pembahasan maka dapat disimpulkan sebagai berikut. Hasil belajar yang menggunakan Metode pembelajaran PQ4R lebih tinggi dibandingkan pembelajaran menggunakan metode konvensional kelas VII SMP Negeri 3 Palangga studi pada materi pokok ekosistem. Jadi, terdapat pengaruh metode pembelajaran PQ4R terhadap hasil belajar peserta didik kelas VII SMP Negeri 3 Palangga studi pada materi pokok ekosistem.

\section{DAFTAR PUSTAKA}

Agus, P.W., I Md, Nyn Wirya, Ign. I Wyn Suwatra. (2014). Pengaruh Metode Pembelajaran PQ4R Terhadap Hasil Belajaripasiswa Kelas VIII Di Smp Negeri 1 Sawan. e-Journal Edutech Universitas Pendidikan Ganesha Jurusan Teknologi Pendidikan. Vol: 2 No: 1.

Andi Afrisal. (2011). Pengaruh Metode PQ4R Terhadap Hasil Belajar Siswa Kelas X SMA Negeri 4 ParePare Pada Materi Ikatan Kimia. (Skripsi). Universitas Negeri Makassar, Makassar.

Dahar.R.W. (2002). Teori-teori Belajar. Jakarta. P2LPTK.

Sudarman. (2009). Peningkatan pemahaman dan daya ingat siswa melalui strategi Preview, Question, Read, reflect, recite, dan Review (PQ4R). Jurnal pendidikan Invatif. Vol.4. No.2.

Sudiarti, Ni Ketut, I Wyn Suwatra, Ni Nyoman Kusmariyatni. (2015). Pengaruh Strategi Pembelajaran PQ4R Berbantuan Peta Konsep Terhadap Hasil Belajar IPA Siswa Kelas IV SD. Jurnal PGSD Vol.3 No 1.

Suyono \& Hariyanto. 2015. Belajar dan Pembelajaran. Bandung: PT Remaja Rosdakarya.

Rahmaniah T., Sutresna I.B., \& Artawan, G. (2016). Penerapan Teknik PQ4R Berbantuan Media Cerpen Untuk Meningkatkan Kemampuan Menulis Naskah Drama Siswa Kelas XI IPB2 Sma Negeri 2 Gerokgak. Universitas Pendidikan Ganesha. e-Journal JPBSI Undiksha. Vol. 4 No. 2.

Trianto. (2007). Model-model pembelajaran Inovatif Berorientasi Kontruktivistik. Jakarta: Prestasi Pustaka.

Trianto. (2009). Mendesain Model Pembelajaran Inovatif-Progresif. Surabaya: Kencena.

Wahyuningsih, A.N. (2012). Pengembangan Media Komik Bergambar Materi Sistem Saraf untuk Pembelajaran Menggunakan Strategi PQ4R. Journal of Innovative Science Education. Vol 5 No 3 .

Wajdi Badrul, Widha Sunarno, Suparmi. 2014. Pembelajaran Fisika Menggunakan Strategi Peta Konsep (Concept Map) Dan Strategi Pq4r (Preview, Questions, Read, Reflect, Recite, And Review) Ditinjau Dari Motivasi Belajar Dan Tingkat Berfikir Abstrak Siswa. Universitas Sebelas Maret. Jurnal Materi dan Pembelajaran Fisika (JMPF).Vol 1. No. 1. 


\author{
Ridha Alfiana \\ Guru mata pelajaran IPA di SMPN 2 Wotu, dapat dihubungi melalui pos-el: \\ ridha.alfiana@gmail.com \\ Ratnawaty Mamin \\ Dosen Program Studi Pendidikan IPA FMIPA UNM, aktif melakukan penelitian pada bidang \\ Pendidikan IPA \\ Sitti Rahma Yunus \\ Dosen Program Studi Pendidikan IPA FMIPA UNM, aktif melakukan penelitian pada bidang \\ Pendidikan IPA
}

